Article

\title{
Integrating Sustainability in the Business Administration and Management Curriculum: A Sustainability Competencies Map
}

\author{
Dolors Gil-Doménech $^{1}{ }^{\mathbb{D}}$, Nina Magomedova ${ }^{1, * \mathbb{C}}$, Eugenio José Sánchez-Alcázar ${ }^{2}$ \\ and Matilde Lafuente-Lechuga ${ }^{3}$ (D) \\ 1 Department of Economy and Business Organization, Faculty of Economic and Social Sciences, Universitat \\ Internacional de Catalunya, 08017 Barcelona, Spain; mdgil@uic.es \\ 2 Department of Applied Economics, Faculty of Economics and Business, Universidad de Murcia, \\ 30100 Murcia, Spain; eugenioj@um.es \\ 3 Department of Quantitative Methods for the Economy and Business, Faculty of Economics and Business, \\ Universidad de Murcia, 30100 Murcia, Spain; mati@um.es \\ * Correspondence: nmagomedova@uic.es; Tel.: +34-930-191-468
}

Citation: Gil-Doménech, D.; Magomedova, N.; Sánchez-Alcázar, E.J.; Lafuente-Lechuga, M. Integrating Sustainability in the Business Administration and Management Curriculum: A Sustainability Competencies Map. Sustainability 2021, 13, 9458. https://doi.org/10.3390/su13169458

Academic Editor: Clemens Mader

Received: 29 June 2021

Accepted: 18 August 2021

Published: 23 August 2021

Publisher's Note: MDPI stays neutral with regard to jurisdictional claims in published maps and institutional affiliations.

Copyright: (c) 2021 by the authors. Licensee MDPI, Basel, Switzerland. This article is an open access article distributed under the terms and conditions of the Creative Commons Attribution (CC BY) license (https:/ / creativecommons.org/licenses/by/ $4.0 /)$.

\begin{abstract}
This study presents a sustainability competencies map (SCM) for Business Administration and Management (BAM) disciplines as a tool to support education in sustainability at the university level. The study describes in detail the design and elaboration of the map based on the competencies defined by the Conference of Rectors of Spanish Universities (CRUE) and complemented with the Sustainable Development Goals (SDG) adopted by the United Nations. In addition, to externally evaluate the proposed SCM, we conducted a series of interviews with top managers and founders of five organizations that vary in size and industry. As the main contribution, the SCM for BAM studies is presented, containing 58 learning objectives. The qualitative research framework performed to obtain evidence from the interviewees showed that the holistic dimension of the proposed SCM is highly valued by the interviewed practitioners. Additionally, the SCM's division of competencies into three levels of achievement was considered practical and helpful to measure them. Finally, the interviewees expressed concerns regarding the implementation of the SCM in real classroom, calling for the necessity of special training for teachers and flexibility of higher education system. Reinforced by the interviewees' opinions, we believe that the SCM for BAM education presented here will facilitate the design of different methodologies by the teaching staff to guide students towards compliance with the 17 SDGs in 2030.
\end{abstract}

Keywords: sustainable development goals; sustainability competencies map; business administration and management education; business administration and management curriculum

\section{Introduction}

During the last three decades, Higher Education Institutions (HEIs) have made a great effort to integrate sustainable development into their traditional functions, such as research activities, training, dissemination, technology transfer and actions for promoting sustainability within the campus [1,2]. Undoubtedly, the approval of the United Nations Decade of Education for Sustainable Development [3] and its subsequent extensions [4,5] generated the necessary framework for most of the HEIs to initiate different actions and progressively integrate sustainability into their institutional practice [6].

To this end, organizations such as the United Nations Global Initiative, Sustainable Development Solutions Network [7,8] or the Global University Network for Innovation [9] carried out the very important task of disseminating the work of universities, mobilizing the experience and resources of academia, civil society and the private sector to provide solutions for sustainable development at the local, national and global levels [10].

However, sustainable development is "a concept that has not penetrated enough and has not done so equally in all university disciplines," [11] (p. 109) nor has it been integrated 
into the universities holistically, but rather has been compartmentalized into some of the sustainability domains [12]. For their part, teachers face several obstacles, among which are the scant training in sustainability and its limitations when integrating it into teaching [12-15]. To overcome these obstacles, Lozano suggests identifying those teachers who are especially aware of curricular sustainability and aiming the training primarily at the "innovators" since these will serve as teaching to the group of "laggards" who will be the last to integrate sustainability into their teaching work [6]. This training should be aimed not only at transmitting sustainability skills to students but also at developing their own skills in this field. This requires a series of innovative teaching and learning practices that enable teachers to go beyond being a mere content transmitter to becoming a dynamic member of the classroom [16].

A further aspect of training concerns university students, who should acquire a series of competencies that enable them to develop specific profiles of their academic specialty, which would also provide a benchmark framework for assessing both learning and teaching effectiveness. However, there is still no agreement on what these key competencies, skills and learning outcomes for sustainability in higher education really are [17]. In this sense, sustainable development can be regarded as a normative starting point for selecting the relevant key competencies [18] that facilitate the acquisition of knowledge and the development of the skills that are expected of them as future agents of change [19,20]. We therefore understand sustainability competencies as a set of knowledge, skills and attitudes that enable the effective resolution of tasks and problems regarding the challenges and opportunities posed by sustainability in the real world [18,21].

Based on Wiek's key sustainability competencies [20], Brundiers et al. [22] (pp. 20-21) proposed two additional competencies. Specifically, the first competency refers to "successfully integrating two or more of the key competencies in sustainability problem-solving endeavors and, ultimately, integrating all key competencies to create viable and equitable solutions for sustainability," while the second one is related to "concepts and methods related to intra-personal or self-awareness competency". In this line, contemplative practices supporting the second competency have been increasingly incorporated into sustainability courses (e.g., $[23,24])$.

Research focusing on sustainability competencies includes, among others, the works of Redman et al. [25], where the assessment of students' sustainability competencies is analyzed; Tamsin and Wiek's study [26] that proposes a framework of sustainability entrepreneurship competencies; de Oliveira et al.'s work [27] that puts forth a method of analysis of the interrelationships between sustainable development and organizational competencies; and the study of Knight and Paterson [28], where key behavioral competencies of corporate sustainability leaders are identified and a model for measuring these competencies is suggested.

According to Olalla and Merino [29], the delimitation of competencies for sustainability is given by the four pillars of lifelong education based on the recommendations of the Delors Report [30]: learn to know, learn to do, learn to live together and learn to be, to which a fifth pillar suggested by UNESCO was added: learn to transform oneself and society [31]. Thus, despite the difficulty of specifying the particular competency of a change agent for sustainability, it can be argued that the analytic framework consisting of the five pillars mentioned above would be appropriate for delimiting this competency. In particular, the fifth pillar seeks to sensitize students to the main systemic challenges so that they can provide innovative responses in a context of complexity and uncertainty [29].

Additionally, significant progress has been made in recent years in the conceptualization of competencies for sustainable development, predominantly in the world of education [18,20,32]. Based on these studies, Dentoni et al. [33] have developed a framework consisting of seven sustainability competencies in the professional environment: systemic thinking competency, foresight competency, normative competency, adoption of diversity and interdisciplinarity, interpersonal competency, action competency and strategic management [34]. 
Specifically, in the field of business administration and management education, where business organizations are regarded not only as a fundamental part of the solution to sustainability crises, but also an important cause, it is difficult to delineate sustainability competencies $[29,35,36]$. Furthermore, the literature in which the profile of this competency in higher education related to business management is studied yields few results [37], and business schools have yet to agree on what constitutes key competencies in the field of sustainability and responsible management education. More debate is needed on what skills future entrepreneurs will need to approach decision-making processes in a more responsible and sustainable way [35].

It is, therefore, especially important that the universities with studies related to the business world and business and management schools are involved in the training of their students so that they are able to provide future business leaders with the skills necessary to face the complexity and uncertainty besetting companies and society $[38,39]$. This is precisely the goal of the United Nations' global initiative launched in 2007-Principles for Responsible Management Education (PRME). These principles emphasize the importance of the Sustainable Development Goals (SDGs) for HEIs in the business and management fields since they have the ability to influence students by teaching them responsible and sustainable business practices, which will shape the business leaders and society of tomorrow [40]. In the work carried out by Godemann [41], some of the positive aspects of the PRME are highlighted, such as the support for the responsible management education initiative by rating and accreditation bodies, which have begun to give greater recognition to the vision of sustainable development within management and leadership education.

The academic research on curricular sustainability in the specific case of the Spanish university system, which is the research setting of the current study, offers a clear consensus on the competencies that should be integrated in all degrees, identified and formulated by the CRUE-Sustainability Sector Commission (CSCS). These appear for the first time in the document Guidelines for the Introduction of Sustainability in the Curriculum, published in 2005 and updated in 2012 [42], and are as follows:

- Critical contextualization of knowledge establishing interrelationships with social, economic and environmental, local and/or global problems;

- Sustainable use of resources and the prevention of negative impacts on the natural and social environment;

- Participation in community processes that promote sustainability;

- Application of ethical principles related to the values of sustainability in personal and professional behavior.

Taking as a starting point these competencies indicated by the CRUE, within the framework of the EDINSOST project (2016-2019), a sustainability competencies map (SCM) for the Business Administration and Management (BAM) degree [43] was designed, and later enriched in the EDINSOST2-SDG project (2019-2023), by relating the learning outcomes of the map (SCM-LOs) with the SDGs' learning objectives (SDG-LOs) defined by UNESCO [21]. In general terms, these projects, funded by the Spanish R\&D\&I Program that has involved a group of researchers from different Spanish universities in the fields of Engineering, Education and BAM, aim at helping universities to better integrate sustainability in the training of students to enable graduates to spearhead the search for sustainable solutions to the challenges facing our society [44]. As will be analyzed later, the work developed within the EDINSOST2-SDG project represents an important qualitative change of the SCM for BAM compared to the one originally designed in EDINSOST, since now the matrix offers specific cognitive, socioemotional and behavioral learning outcomes for each objective that allow people to address the particular challenges of each SDG, thus facilitating their achievement.

At this point, it is important to distinguish between learning objectives and learning outcomes. According to Hartel and Foegeding [45], while the former are the expected goals of an educational activity, course or program, the learning outcomes describe what students will be able to do in a measurable way after participating in it. 
This paper presents the SCM for BAM disciplines, developed in the framework of the EDINSOST2-SDG project, as a tool to support education in sustainability at the university level. The process of elaboration and integration of the SDG-LOs into the map is explained in detail. Moreover, the results of several interviews carried out with different types of companies are shown in order to determine their opinion regarding the SCM for BAM of those external agents who are ultimately the main recipients of the students who are being trained in the framework of this project.

\section{Materials and Methods}

\subsection{SDG-LOs to Be Developed in BAM Curricula}

UNESCO [21] defined 15 LOs for each of the 17 SDGs classified into the three levels:

- Cognitive learning (C): 5 objectives that comprise the knowledge and thinking tools necessary to better understand a given SDG and the challenges involved in its achievement;

- Socioemotional (S): 5 goals that include social skills that empower students to collaborate, negotiate and communicate to promote the SDGs, as well as self-reflective values, attitudes and incentives that enable them to develop.;

- Behavioral (B): 5 objectives that describe action skills.

In total, UNESCO defined 255 SDG-LOs that should be developed at different educational levels. Within the framework of the EDINSOST2-SDG project, each of them has been assigned to one of the following three categories:

- $\quad$ SDG-LOs that must be developed in all BAM curricula, so that they should have an exact match with an SCM-LO in the SCM for BAM;

- $\quad$ SDG-LOs that must be developed in one or more curricula related to the business or economic field, so that they should be related with an SCM-LO in the SCM for BAM;

- $\quad$ SDG-LOs that must be developed in university courses other than BAM, in nonuniversity studies or simply throughout life, so that they should not appear in the SCM for BAM.

The methodology followed to assign each SCM-LO to the SDG-LOs while developing the SCM for BAM was applied simultaneously in the two faculties involved in the process: the Universidad de Murcia Faculty of Economics and Business and the Universitat Internacional de Catalunya Faculty of Economic and Social Sciences. This consisted of the following steps:

- Each of the faculties (with 4 researchers in each) formed an independent working group.

- The 17 SDGs were divided into two sets, and one was assigned to each group.

- Each group independently reviewed the SDG-LOs of the assigned SDGs and classified them in each of the three previously described categories. The SDGs of the other set were then reviewed. To ensure uniformity of criteria and to avoid discrepancies regarding the other work groups in the project, this process was carried out under the guidance of a member of the research team in the field of engineering, which had previously worked in their field categorization and had established the allocation criteria.

- Once the 255 SDG-LOs had been independently categorized, the results were shared.

- Finally, and again under the supervision of the representative from the engineering field, a meeting was held to review and discuss any discrepancies that might exist and to make the final assignment.

\section{2. $S C M$ for $B A M$}

A competency map is key to optimally develop SDGs in the university system [46]. It is important to determine what aspects must be improved and what training must be acquired by students to advance their knowledge and ability to apply sustainability competencies. This map forms the basis on which teachers begin to advance once they have identified the knowledge, skills and attitudes necessary for acquiring all the competencies in 
Sustainability, and also serves as a guide for implementing and evaluating the development of these competencies in university curricula. At the same time, it provides a very useful methodology for effectively integrating professional competencies into study plans.

SCM for BAM has been constructed according to the work by Sanchez Carracedo et al. [43] and Sanchez Carracedo et al. [47] where the origin, evolution and main elements that make up the map are analyzed. This map is a double entry matrix that describes the development of a competency in the subjects of a degree.

The methodology followed to prepare the SCM for BAM was applied simultaneously and in a similar way to that described in the previous section by the two working groups of the two faculties of the BAM field under the supervision of a representative of the field of engineering, and consisted of the following steps:

- Taking as a starting point the SCM developed in the EDINSOST framework [43,47], one of the groups related the SDG-LOs that should be developed in BAM to the SCM-LOs. Following that process, it was necessary to rewrite some of the SCM-LOs in order to obtain a better match with SDG-LOs, while, in other cases, new LOs had to be added to the map.

- The second group then monitored the work done by the first group and any discrepancies in criteria that emerged were discussed before the final drafting of the SCM-LOs that make up the SCM for BAM under the EDINSOST2-SDG project were agreed upon. It should be said that, although not all the SCM-LOs are related to the SDG-LOs, they are all related to the SDGs.

- Finally, the differences between the SCM for BAM and those of the other degrees of the project (Engineering and Education) were discussed, taking into account the transversality envisaged within the framework of the project, the aim of which is to ensure that the resulting maps of the different degrees are transferable to other areas of education. The final numbering of the LOs follows this criterion of transversality, so that the LOs that are similar in the three maps have the same associated numbering.

\subsection{SCM's External Evaluation}

To receive feedback from the real employers of future graduates, a qualitative descriptiveinterpretive research was carried out using personal semi-structured interviews as a technique for collecting information, the objectives of which are as follows:

- To externally validate the map through the qualitative evaluation of stakeholders, such as company representatives, not directly involved in the EDINSOST2-SDG project;

- To receive feedback on this tool from those who, on the one hand, are emerging as future employers of the students involved in the project and who, on the other hand, may have a direct impact on the different dimensions of sustainability-environmental, economic and social.

Next, Figure 1 shows, as a flowchart, the methodology followed for the preparation of the SCM for BAM, from the selection of the SDGs to the final external validation that has been explained above. 


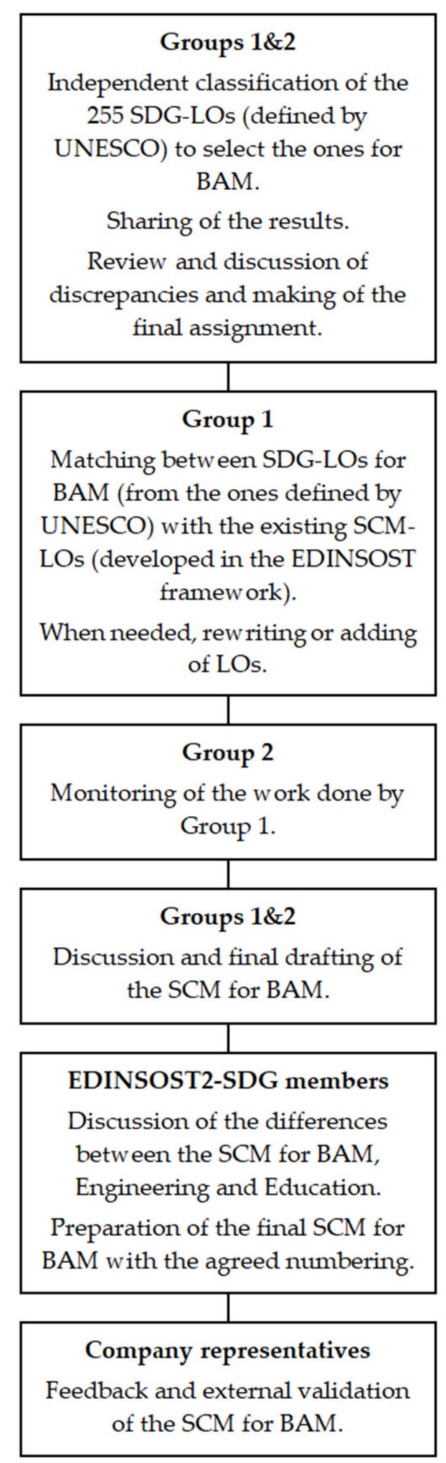

Figure 1. Flowchart showing the steps followed for the development of the SCM for BAM.

\subsubsection{Sample Selection and Description}

In a similar way to that followed in Gil-Doménech et al. [48], the selection of the sample responded to the following criteria:

- Companies of different sizes and orientations (multinational, SME, start-up, social enterprise and NGO);

- Companies from different sectors closely related to some dimension of sustainability or to the area in which the EDINSOST2-SDG project is developed (i.e., higher education).

As a result, we selected top level managers and/or founders of five companies. In this aspect, we followed the recommendations of Polkinghorne [49] that suggests selecting a minimum of five information-rich heterogeneous interviewees, where insights saturation for research topics of a narrower scope and more 'obvious' nature (as in the case of qualitative evaluation) typically occurs. Table 1 presents the sample, in which different characteristics can be observed, such as the sector in which the interviewed companies operate, their size and geographic location, among others. As can be perceived, all the companies belong to different industrial sectors and vary in size and in the centrality of social/environmental components of their strategic missions. Such a purposeful sampling approach not only increases the transferability of the obtained results which is so sought after in qualitative research but also ensures the receipt of a rich, multifaceted vision of the studied phenomenon as recommended in Olsson et al. [50]. 
Table 1. Sample description.

\begin{tabular}{ccccccc}
\hline N. & Firm Code & Location & Industry & Size (Employees) & $\begin{array}{c}\text { Interviewee } \\
\text { Position }\end{array}$ & $\begin{array}{c}\text { Interviewee } \\
\text { Duration }\end{array}$ \\
\hline 1 & MNC & Casablanca & Food and Beverage & more than 4000 & Legal counsel & 40 min \\
2 & NGO & El Prat de Llobregat & Agriculture & between 20 and 50 & Project manager & 35 min \\
3 & SME & Barcelona & Hostelry & between 5 and 15 & Founder & 30 min \\
4 & COOP & Manresa & Textile & between 50 and 100 & Founder & 40 min \\
5 & SPIN OFF & Murcia & Consultancy & between 5 and 15 & Founder & 35 min \\
\hline
\end{tabular}

\subsubsection{Information Collection and Analytical Tools}

The interview was jointly designed by the two BAM universities in the EDINSOST2SDG project, the Universitat Internacional de Catalunya and the Universidad de Murcia, under the supervision and guidance of the principal investigators of the project.

As can be seen in Table 2, it was decided to start by asking more general questions about what each interviewee understands by sustainability (Question 1) to ensure that the interviews were conducted within a common framework in which sustainability was considered holistically in all its dimensions. It was also considered appropriate to ask about their knowledge or application of instruments for measuring sustainability competencies (Question 2), in order to determine whether or not their opinions were based on the knowledge and comparison of similar tools. Next, once the framework in which the interview was conducted was established, a block of questions was posed about the SCM for BAM, which is divided into three main lines:

1. Usefulness of competency education (Question 3);

2. Usefulness and content of the SCM for BAM (Questions 4, 6 and 7);

3. Adjustment of the SCM for BAM to the requirements of the company (Question 5).

Table 2. Questions to be asked in the company interviews.

\begin{tabular}{|c|c|c|}
\hline N. & Question & Category \\
\hline 1 & What do you understand by sustainability? & Notion of sustainability \\
\hline 2 & $\begin{array}{l}\text { Do you know of any instrument for measuring sustainability } \\
\text { competencies? If so, do you apply this/these measurement tool(s) } \\
\text { in your company? }\end{array}$ & Similar tools \\
\hline 3 & $\begin{array}{l}\text { Do you believe that competency education is an appropriate } \\
\text { framework for fostering sustainability among university students? } \\
\text { Why? }\end{array}$ & Education in competencies \\
\hline 4 & $\begin{array}{c}\text { Having had the SCM for BAM explained to you, and having been } \\
\text { able to analyze it, do you think it would be a suitable tool for } \\
\text { supporting education in sustainability competencies at the } \\
\text { university? Why? }\end{array}$ & Usefulness and content of the map \\
\hline 5 & $\begin{array}{l}\text { How do the learning outcomes reflected in the map (SCM-LOs) } \\
\text { match the learning outcomes your company seeking in its } \\
\text { employees? In this sense, do you think differences exist between } \\
\text { the sustainability competencies you seeking in senior vs. younger } \\
\text { employees (generation Z)? Why is this? }\end{array}$ & $\begin{array}{l}\text { Adjustment to the requirements of the } \\
\text { company }\end{array}$ \\
\hline 6 & What do you consider to be the strengths of the SCM for BAM? & Usefulness and content of the map \\
\hline 7 & Have you any suggestions for improvement (of the SCM for BAM)? & Usefulness and content of the map \\
\hline
\end{tabular}

Contact with the interviewees was conducted in four phases:

- An initial contact via email or phone call with the company in order to confirm their availability and interest in collaborating with the study. In this first contact, a general explanation of the project is given, together with the context in which it is framed, as well as the main objective of the interview; that is, to test externally through an agent of special interest for the project, such as the company, the usefulness of the SCM for BAM and its adjustment to market requirements. 
- Next, two documents are sent via email. The first one contains a more detailed explanation of the EDINSOST2-SDG project and its objectives, as well as a brief description of the 2030 Agenda on sustainable development approved in 2015 by UNESCO and the SDGs contained therein. This same document details the objectives of the interview as well as the questions to be asked, so that companies can prepare in advance. The second document contains the competency map.

- Once the company has all the information, a new contact is established (by telephone or in person) to explain the SCM for BAM firsthand and resolve any doubts that may have arisen.

- The interview itself is conducted approximately one week later. Of the 5 interviews, 2 were conducted in person and 3 by video call. With the approval of the company, these interviews were recorded in order to proceed later to the transcription and analysis of the answers.

Content analysis was used to process the qualitative information. First, the transcribed interviews were analyzed by the four researchers independently and manually, and the preliminary coding procedure was performed. Manual coding is appropriate for smaller projects that require depth of the interpretive analysis. The codes were then compared among the four researchers and triangulated with the existing concepts found in the literature review. This step enabled the researchers to reduce the first order codes to a total of 11 secondary codes, which, afterwards, were aggregated into higher order dimensions, as recommended by Gioia et al. [51]. Additionally, the qualitative research did not reveal a necessity to adjust the SCM or make any changes in it. However, the interviewees did express some concerns in terms of the practical application of this tool. We will develop these insights in the following section.

\section{Results}

\subsection{SDG-LOs to Be Developed in BAM Curricula}

To analyze whether the SDG-LOs related to BAM are in fact covered by the LOs of BAM degrees, and according to the criteria explained in Section 2.1, a matrix was constructed in which the rows contain the SDG-LOs according to the categories Cognitive (C1-C5), Socioemotional (S1-S5) and Behavioral (B1-B5), and the columns contain the 17 SDGs. Figure 2 shows this matrix, where cells are named and colored according to following criteria:

- $\quad$ SDG-LOs to be developed in all BAM curricula so that they should be in the SCM for BAM ("BAM" category, in orange);

- $\quad$ SDG-LOs that must be developed in one or more curricula related to the business or economic fields so that they should be related with an SCM-LO in the SCM for BAM ("Any BAM" category, in green);

- SDG-LOs that must be developed in other university careers other than BAM, in non-university studies or simply throughout life, so that they should not be in the SCM for BAM ("Other" category, in red).

Figure 2 shows that of the total number of SDG-LOs (255), 32 (12.5\%) are related to BAM (whether in "BAM" (18) or "Any BAM" (14)) categories and thus should be reflected in the SCM for BAM. For SDG10 (Reduced Inequalities) the largest number of SDG-LOs coincide or are related to the SCM-LOs. Specifically, there are four exact matches (two cognitive and two behavioral, corresponding to the "BAM category") and five SDG-LOs that partially coincide with the SCM-LOs (one cognitive, one socioemotional and three behavioral, corresponding to the "Any BAM" category), comprising $28.1 \%(9 / 32)$ of the total BAM-related SDG-LOs in Figure 2. The next SDG with more SDG-LOs that are BAM-related and thus should be reflected in the SCM for BAM is SDG1 (No Poverty), which contains five SDG-LOs (15.6\% of the 32 in total), two of them (both behavioral) in the "BAM" category and three (two cognitive and one behavioral) in the "Any BAM" category. Next, SDG12 (Responsible Consumption and Production) and SDG9 (Industry, Innovation and Infrastructure) each contain 12.5\% (4/32) of the BAM-related SDG-Los. For SDG12, 
there are three SDG-LOs (one cognitive and two behavioral) in the "BAM" category and one SDG-LO (cognitive) classified as "Any BAM". Meanwhile, for SDG9, only one SDG-LO (behavioral) belongs to the "BAM" category, and the other three BAM-related SDG-LOs (cognitive) are considered as "Any BAM". Then, the SGD with more SDG-LOs that should correspond to SCM-LOs in the SCM for BAM are, respectively, SDG3 (Good Health and Well-being) and SDG8 (Decent Work and Economic Growth), each with 9.4\% (3/32) of the cases, followed by SDG17 (Partnership for the Goals) with $6.3 \%(2 / 32)$ of the cases and SDG11 (Sustainable Cities and Communities) and SDG6 (Clean Water and Sanitation), each with $3.1 \%(1 / 32)$ of the cases.

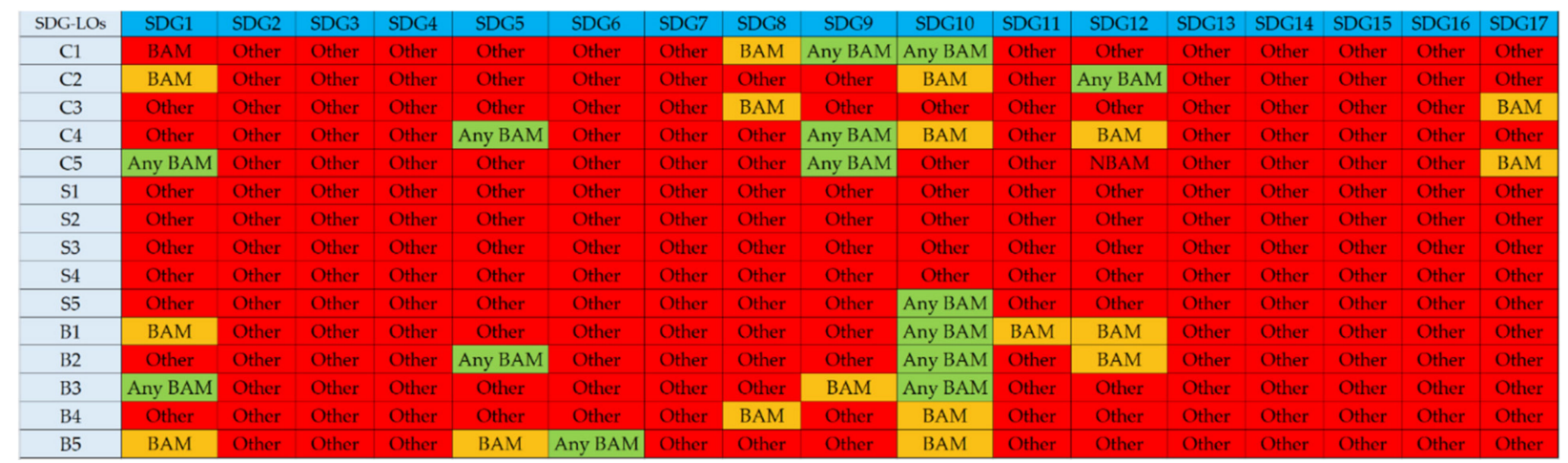

Figure 2. Classification of SDG-LOs according to the taxonomy described ("BAM": SDG-LOs to be developed in all BAM curricula; "Any BAM": SDG-LOs to be developed in one or more curricula related to the business or economic fields; "Other": SDG-LOs to be developed in other university careers other than BAM, in non-university studies or throughout life).

If the 32 BAM-related SDG-LOs are more closely analyzed taking into account their classification by UNESCO as cognitive (C), socioemotional (S) or behavioral (B), Figure 3 is obtained. Thus, Figure 3 shows, for each of the 32 BAM-related SDG-LOs ("BAM" and "Any BAM" categories from Figure 2), their classification as C, S or B according to UNESCO. From Figure 3, it can be observed that the majority of them are either behavioral $(16 / 32=50 \%)$ or cognitive $(15 / 32=46.9 \%)$, while only one $(3.1 \%)$ is socioemotional. This implies that four socioemotional objectives (S1-S4) exist that are not specifically addressed in BAM disciplines, but rather in university courses other than BAM, in non-university studies or simply throughout life (belonging to the "Other" category).

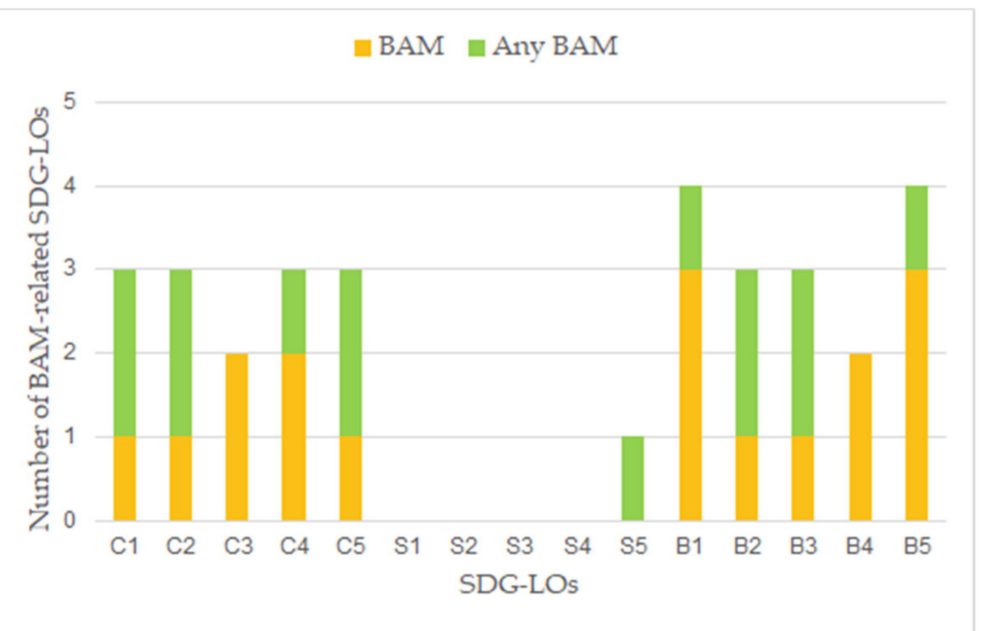

Figure 3. Number of BAM-related SDG-LOs according to UNESCO's SDG-LOs classification (C: cognitive, S: socioemotional, B: behavioral).

Finally, Figure 4 shows how many SCM-LOs are related to each SDG (in pink) and how many of those SCM-LOs come from BAM-related SDG-LOs (in blue). In other words, 
Figure 4 shows to which SDGs the LOs on the SCM for BAM relate (in pink) and how many of these SCM-LOs are derived from the LOs defined by UNESCO (in blue).

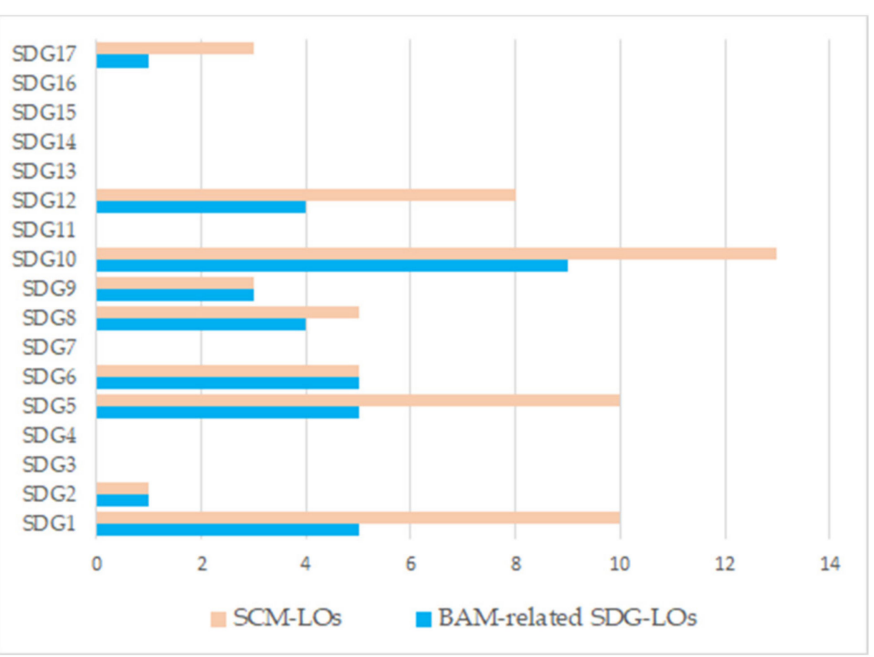

Figure 4. SCM-LOs and BAM-related SDG-LOs for each SDG.

Figure 4 shows, for example, that SDG10 is present in a greater number of SCM-LOs (13), of which nine correspond to BAM-related SDG-LOs. Next, SDG5 and SDG1, each with 10 SCM-LOs associated, 50\% of which (5) being BAM-related SDG-LOs. In total, there are 58 SCM-LOs, of which 37 (63.8\%) correspond to BAM-related SDG-LOs.

\section{2. $S C M$ for $B A M$}

The SCM for BAM was created following the procedure explained in Section 2.2. The rows of the map are defined on the basis of the four competencies related to sustainability established by the CRUE (SOS1-SOS4), each of which has been mapped in the form of a Competency Unit (CU) defined by the three dimensions of sustainability (environmental, economic and social) plus a holistic dimension. As reflected in Table 3, SOS2 competency is the only one that relates independently to the three dimensions of sustainability (economic, social and environmental) along with the holistic view. The remaining competencies deal only with sustainability in a holistic manner. For each CU, SCM-LOs have been defined and classified into three levels. For this purpose, a simplified version of Miller's Pyramid [52] has been used as a taxonomy. This taxonomy has been reduced to only three levels of mastery by combining the two highest levels ("Demonstrate" and "Do") into one. Thus, the domain levels used in the SCM are: "Know", "Know how" and "Demonstrate + Do".

Based on the above considerations, Table 3 shows the SCM for BAM, with a total of 58 SCM-LOs. The first two columns of the map correspond, respectively, to the SOS1-SOS4 competencies established by the CRUE and to the dimensions (HO-holistic; $\mathrm{EN}$ - environmental; SO-social; EC-economic). The third column is formed by the CU identified for each of the competencies in sustainability. The last three columns contain the SCM-LOs for each level of mastery that students should achieve at the end of their degree.

The full list of SCM-LOs, developed with the coding specified for them by the EDINSOST2-SDG team is provided in the Appendix A.

Based on the SCM for BAM, it is expected that pathways can be established for each competency in sustainability in the BAM context in which the levels of mastery, the LOs, the contents and the subjects to which they belong are known. 
Table 3. SCM for BAM with the numbering coding proposed for the SCM-LOs.

\begin{tabular}{|c|c|c|c|c|c|}
\hline \multirow{2}{*}{ CRUE Competency } & \multirow{2}{*}{ Dimension * } & \multirow{2}{*}{ Competency Unit } & \multicolumn{3}{|c|}{ Domain Levels } \\
\hline & & & Know & Know How & Demo + Do \\
\hline $\begin{array}{l}\text { C1: Critical contextualization of } \\
\text { knowledge establishing } \\
\text { interrelations with social, economic } \\
\text { and environmental, local and/or } \\
\text { global problems. }\end{array}$ & $\mathrm{HO}$ & $\begin{array}{l}\text { 1. Has a historical and current } \\
\text { perspective and understanding of the } \\
\text { systemic nature of environmental, } \\
\text { social and economic problems, as well } \\
\text { as their interrelationships and future } \\
\text { challenges, both local and global. }\end{array}$ & $\begin{array}{l}\text { C1.HO.1.1 } \\
\text { C1.HO.1.2 } \\
\text { C1.HO.1.3 }\end{array}$ & C1.HO.2.1 & C1.HO.3.1 \\
\hline & EN & $\begin{array}{l}\text { 2. Is able to detect and analyze the } \\
\text { environmental impact of their } \\
\text { professional activity and to propose } \\
\text { sustainable solutions. }\end{array}$ & $\begin{array}{l}\text { C2.EN.1.1 } \\
\text { C2.EN.1.2 }\end{array}$ & $\begin{array}{l}\text { C2.EN.2.1 } \\
\text { C2.EN.2.2 }\end{array}$ & $\begin{array}{l}\text { C2.EN.3.1 } \\
\text { C2.EN.3.2 } \\
\text { C2.EN.3.3 }\end{array}$ \\
\hline & SO & $\begin{array}{l}\text { 3. Is able to detect and analyze the } \\
\text { social impact of their professional } \\
\text { activity and to propose sustainable } \\
\text { solutions. }\end{array}$ & $\begin{array}{l}\text { C2.SO.1.1 } \\
\text { C2.SO.1.2 }\end{array}$ & $\begin{array}{l}\text { C2.SO.2.1 } \\
\text { C2.SO.2.2 }\end{array}$ & $\begin{array}{l}\text { C2.SO.3.1 } \\
\text { C2.SO.3.2 }\end{array}$ \\
\hline $\begin{array}{c}\text { C2: Sustainable use of resources } \\
\text { and prevention of negative impacts } \\
\text { on the natural and social } \\
\text { environment. }\end{array}$ & EC & $\begin{array}{l}\text { 4. Is able to manage the material, } \\
\text { economic and human resources of the } \\
\text { project in their professional field with } \\
\text { sustainability criteria to ensure the } \\
\text { project's economic viability. }\end{array}$ & $\begin{array}{l}\text { C2.EC.1.1 } \\
\text { C2.EC.1.2 }\end{array}$ & $\begin{array}{l}\text { C2.EC.2.1 } \\
\text { C2.EC. } 2.2 \\
\text { C2.EC. } 2.3\end{array}$ & $\begin{array}{l}\text { C2.EC.3.1 } \\
\text { C2.EC.3.2 } \\
\text { C2.EC.3.3 } \\
\text { C2.EC.3.4 }\end{array}$ \\
\hline & $\mathrm{HO}$ & $\begin{array}{l}\text { 5. Is able to detect and analyze the } \\
\text { environmental, social and economic } \\
\text { impact of their professional activity } \\
\text { and to propose, design, organize and } \\
\text { carry out sustainable actions. }\end{array}$ & $\begin{array}{l}\text { C2.HO.1.1 } \\
\text { C2.HO.1.2 } \\
\text { C2.HO.1.3 } \\
\text { C2.HO.1.4 }\end{array}$ & $\begin{array}{l}\text { C2.HO. } 2.1 \\
\text { C2.HO. } 2.2 \\
\text { C2.HO. } 2.3 \\
\text { C2.HO. } 2.4\end{array}$ & $\begin{array}{l}\text { C2.HO.3.1 } \\
\text { C2.HO.3.2 } \\
\text { C2.HO.3.3 } \\
\text { C2.HO.3.4 }\end{array}$ \\
\hline $\begin{array}{l}\text { C3: Participation in community } \\
\text { processes that promote } \\
\text { sustainability. }\end{array}$ & $\mathrm{HO}$ & $\begin{array}{l}\text { 6. Is able to participate in inclusive } \\
\text { reflection and decision-making } \\
\text { processes with a global citizenship } \\
\text { perspective and to work from their } \\
\text { professional field on interdisciplinary } \\
\text { and transdisciplinary projects that } \\
\text { guide society towards sustainable } \\
\text { transition. }\end{array}$ & $\begin{array}{l}\text { C3.HO.1.1 } \\
\text { C3.HO.1.2 } \\
\text { C3.HO.1.3 }\end{array}$ & C3.HO.2.1 & $\begin{array}{l}\text { C3.HO.3.1 } \\
\text { C3.HO.3.2 }\end{array}$ \\
\hline $\begin{array}{l}\text { C4: Application of ethical principles } \\
\text { related to the values of } \\
\text { sustainability in personal and } \\
\text { professional behavior. }\end{array}$ & $\mathrm{HO}$ & $\begin{array}{l}\text { 7. Behaves in accordance with the } \\
\text { ethical and deontological principles } \\
\text { related to the values of sustainability. }\end{array}$ & $\begin{array}{l}\text { C4.HO.1.1 } \\
\text { C4.HO.1.2 } \\
\text { C4.HO.1.3 } \\
\text { C4.HO.1.4 }\end{array}$ & $\begin{array}{l}\text { C4.HO.2.1 } \\
\text { C4.HO.2.2 }\end{array}$ & $\begin{array}{l}\text { C4.HO.3.1 } \\
\text { C4.HO.3.2 }\end{array}$ \\
\hline
\end{tabular}

${ }^{*}$ HO: holistic, EN: environmental, SO: social, EC: economic.

\subsection{Results of the Qualitative Research}

The qualitative research performed to obtain evidence on the competencies map from the companies' representatives enabled us to gain some interesting insights. Following the coding procedure, we group the results into those related to (1) the internalization of sustainability by the companies, (2) the strong points of the map as perceived by the interviewees, (3) the concerns related to the map, as expressed by the interviewees and (4) the organizational necessities when dealing with sustainability issues (Figure 5). 


\begin{tabular}{|c|c|c|}
\hline $\begin{array}{l}\text { Employees often perceive organizational sustainability as policies that benefit them, such as work schedule flexibility, } \\
\text { healthy environment and good working conditions. The importance of sustainability for the employees varies and } \\
\text { depends on the personal consciousness rather than level of education, or the objectives of the firm itself. }\end{array}$ & $\begin{array}{c}\text { Employees' understanding of } \\
\text { sustainability }\end{array}$ & \\
\hline $\begin{array}{l}\text { Understanding of sustainability as only environmental or only social, lack of the understanding of sustainability as a } \\
\text { holistic concept. }\end{array}$ & $\begin{array}{c}\text { Organizational definition of } \\
\text { sustainability }\end{array}$ & \\
\hline $\begin{array}{l}\text { Existence of certifications of regional, national or/and international level, such as: Balanç Social, SROI, } \\
\text { CAEM/CCPAE,. Presence of firm's own techniques to measure sustainability in firms with strong social mission. Mix } \\
\text { of quantitative and qualitative techniques to measure sustainability. }\end{array}$ & Mechanisms to measure sustainability & \\
\hline $\begin{array}{l}\text { Sustainability's holistic vision that integrates the three dimensions is seen as the only true sustainability. Lack of } \\
\text { understanding of sustainability as holistic by the firms themselves is seen as a handicap, in turn the map shows them } \\
\text { how to change this understanding. }\end{array}$ & Holistic axis of sustainability & \\
\hline $\begin{array}{l}\text { Dividing competencies into three levels makes them more measurable, less abstract and more practical. The three-level } \\
\text { approach shows the direction towards achieving mastery in these competencies. Getting to the third level seems to be of } \\
\text { a primordial importance for students to be ready to implement these competencies in real life. }\end{array}$ & The three-level competencies & \\
\hline $\begin{array}{l}\text { The map is perceived as interesting from the theoretical viewpoint, but difficult to implement in practice. The } \\
\text { transferability of the map to all subjects of the BAM degree seems difficult if possible at all (such area as accounting } \\
\text { arouse the biggest concern). }\end{array}$ & Practical application in the classroom & \\
\hline $\begin{array}{l}\text { Given the fact that the university professors tend to be overloaded by work, there was a concern about their willingness } \\
\text { to adapt teaching guidelines and exercises to the sustainability competencies. The transversal character of competencies } \\
\text { requires sustainability to come out of silos of some separate topics, and to transcend the contents of some specific } \\
\text { subject, which in practice might meet resistance from professors. }\end{array}$ & $\begin{array}{l}\text { Lack of flexibility of the educational } \\
\text { system to extrapolate sustainability }\end{array}$ & elated \\
\hline $\begin{array}{l}\text { To teach sustainability, one first needs to have a deep understanding of the concept, and see how it resonates in the } \\
\text { subject. Therefore, for teachers to be able to teach competencies of sustainability they need to receive education first. }\end{array}$ & $\begin{array}{l}\text { Lack of understanding of } \\
\text { sustainability by the teachers }\end{array}$ & \\
\hline $\begin{array}{l}\text { The importance of the critical approach towards sustainability, ability to differentiate between greenwashing and true } \\
\text { sustainability, have a discourse on and think in terms of sustainability, not just knowledge of the concept itself, is also } \\
\text { crucial. }\end{array}$ & Critical thinking of employees & \\
\hline $\begin{array}{l}\text { There exist numerous tools to measure social and environmental impact that are part of organizational sustainability. } \\
\text { However, few professionals know about these tool, and know how to apply them. The education in this field is } \\
\text { indispensable to be able to put sustainability into practice. }\end{array}$ & $\begin{array}{c}\text { Knowing and handling of the existing } \\
\text { instruments to measure impact }\end{array}$ & $\begin{array}{l}\text { zational } \\
\text { sities }\end{array}$ \\
\hline $\begin{array}{l}\text { The real change is always led by visionary leader, not customers nor employees. Therefore, the education in } \\
\text { sustainability of the future leaders is crucial. }\end{array}$ & $\begin{array}{l}\text { Leaders with the vision of } \\
\text { sustainability as a strategic tool }\end{array}$ & \\
\hline
\end{tabular}

Figure 5. Data analysis and coding procedure. 


\subsubsection{Internalization of Sustainability}

The first line of interview questions was related to the concept of sustainability itself and its implementation and measurement within the company. First, we detected that the understanding of this concept by the managerial staff is different from that of the employees. In fact, managers expressed no concern for the fact that not all employees understand the concept or share their vision of it with the organization. This was true even for the social enterprises where the social dimension of sustainability is engrained in the very mission of the company. The founder of the company explained it as follows: "Not all employees share the same vision of the importance of sustainability and the social impact generated by our company, even though some of them are direct beneficiaries of this impact. However, on the level of top management, where strategic decisions are mostly made, we share the same vision, give the same meaning to sustainability, and this is more important". The interviewees explain that in the long term the company is shaped by the team that leads it, and the employees become "infected" by their leaders and either align with the company's vision organically or leave the company.

Another insight obtained from the interviews was the organizational vision of the concept of sustainability. In particular, the majority of the interviewees did not perceive sustainability as a holistic three-dimensional concept but gave priority to either environmental or social dimensions. This priority of one of the dimensions was given according to the strength of the company: if they were stronger at environmental sustainability, then the environmental dimension was given a priority; when the social impact prevailed, then the sustainability was seen from the perspective of social dimension.

Finally, the interviewees were aware of different instruments for evaluating their social and/or environmental impact, and some of them applied these instruments internally. Moreover, and given the novelty of the majority of the existing tools, some companies drew up their own metrics, both qualitative and quantitative, to measure their social and/or environmental impact, for internal communication and for dissemination among their shareholders/donors (as in the case of NGOs).

The above insights show that there is no universally accepted understanding of the concept of sustainability, even among various stakeholders within the same company. The possible effects of this insight will be discussed later on in this study.

\subsubsection{Map Strengths}

After receiving the explanation of the competencies map, the interviewees were asked about its main strengths. Interestingly, the majority of them highlighted the holistic axis of the competencies map as the main strength. This insight is somewhat related to the finding explained below - the vision of sustainability as unidimensional. In this sense, the map was revelatory for some of the interviewees, as it made them aware of the weaknesses of their vision of sustainability. As the founder of COOP said: "The social dimension is very strong in our company, but we are somewhat handicapped in the environmental dimension. This map shows it very clearly, and we need to work on it to be truly sustainable". For the SME founder, this map was revelatory in the sense that they did not perceive their managerial practices as sustainable: "It is a common sense to treat your employees with dignity, provide good working conditions, give them flexibility to reconcile work and family life, but it is also true that in our sector [hospitality] it is, unfortunately, not that common".

Another strength highlighted by the interviewees was the division of the competencies into three levels. The interviewees saw this as practical: "The schematic layout of the competencies makes it easier to apply them for sustainable development and training and for measuring their achievement" (MNC). This also helps to compensate for the vagueness or absence of universal measurement tools for sustainability. Additionally, according to the interviewees, achieving the third level-knowing how to do-would provide additional value. In this regard, they highlighted the importance of striving to achieve this learning result in future employees and leaders of the business world: "Getting to this third level, in my opinion, is of a 
primordial importance for students to be ready to implement sustainability-related competencies in real life" (COOP).

Thus, the clear strengths of the map, as perceived by the interviewees are, on the one hand, its comprehensive understanding of the concept of sustainability, thanks to the holistic dimension, and on the other hand, the division of the competencies into three levels of expertise, which makes it more concrete and measurable. These findings complement those highlighted in the internalization of sustainability and shed additional light on the importance of the understanding of sustainability as holistic by organizational leaders and employees, as well as on the need to approach the concept as something measurable and achievable.

\subsubsection{Map-Related Concerns}

The main concerns about the map were those regarding its practical implementation: how it will be embodied in a real classroom. These concerns were coded into those related to the subject itself, the transcendentality of sustainability that the map is intended to achieve and finally, and most importantly, the teachers. Initially, some concerns were associated with the limitations of the concept of sustainability when introducing it into some business areas: "I do not see how an accounting professor could work sustainability competencies in their classes" (NGO). A similar concern was expressed by the SME when speaking about their employees: "I understand the importance of knowledge about sustainable business administration or human resource management practices for organizational leaders, but I do not see how a salesperson in a small store could implement sustainability in his/her daily practices" (SME).

This issue was closely related to the second concern detected in the analysis, which is the tendency to put all sustainability-related issues into silos, either in the curriculum of the subjects (separate topics dedicated to sustainability) or in the curriculum of the degree programs (special subjects like Social Entrepreneurship or Business Ethics). The major concern in this regard was about the adaptation of the curricula of multiple subjects, and the willingness of the teachers in charge of all the work associated with it: "The university teachers seem to be overloaded by work, and the idea that they will need to redraw their curricula anew seems implausible" (NGO). In line with this concern, the interviewees underlined the importance of this exact transcendentality of sustainability in the curricula of subjects and degrees, highlighting that "hiding" sustainability, as one COOP interviewee expressed it, within specific topics on sustainability in a subject could not lead to the desired result.

Finally, the third concern expressed by the interviewees was the education of the teachers themselves: "If the teachers sometimes struggle to explain what sustainability is and how it is applied in their subject, how can we expect them to be able to transmit this competency to students?" (NGO). In this sense, the interviewees underlined the importance of first educating teachers about sustainability, thereby helping them to introduce the concept into their curricula transversally and only then apply this map: "The change that you are proposing with this map is indispensable, but the higher education system needs to be ready for this change, otherwise it will all remain in a nice theoretical model that will never go into practice" (COOP).

Duly and mutually aligned, these insights imply the need for preparatory work in order to introduce the competencies map into sustainability effectively. They will be further considered in the Discussion section.

\subsubsection{Organizational Necessities}

The fourth and final group of codes was related to the needs of the organization in regard to the sustainability competencies of future managers and employees.

First, the interviewees expressed their concerns about the ability of critical thinking of future employees and managers when dealing with sustainability: "It is important for students to have their own discourse about sustainability, to be critical about sustainable practices implemented by companies, to be able to evaluate them as truly sustainable or just greenwashing" 
(COOP). They stressed that sustainability can only be achieved by hard work from all the organizational stakeholders and emphasized that without critical thinking and critical selfassessment (on the organizational and individual level) it will be very difficult to achieve the desired change. More importantly, the absence of critical thought when educating in sustainability could result in a shallow understanding of this concept, which in turn could lead to conscious or unconscious malpractices.

Second, since some of the interviewees' companies implement sophisticated tools for measuring their social and environmental impacts, it is vital for them to learn about these tools themselves. In this regard, the interviewees stressed the importance of educating about the reliable measurement tools available, starting from the environmental impact of the students' own activities: "The students need to know how to calculate their own environmental footprint, for example, as it will allow them to evaluate how sustainable their lifestyle is, and be able to change it accordingly, before changing anything in the organization where they come to work" (NGO). Furthermore, educating business administration students on the tools that already exist for measuring social and environmental impact or sustainability levels will enable them to contribute this knowledge to the companies where they will work or lead in the future.

Finally, and in line with the last argument, some of the interviewees expressed the importance of instilling future leaders with the vision of sustainability as a strategic tool, not simply as a moral obligation towards their own and successive generations: "The real change is always led by visionary leaders, not employees or customers" (COOP). They believe that the change towards sustainability will be either voluntary, led by visionary leaders or imposed by the necessity to adapt business practices to the directives of the EU. In this sense, they stressed the EU guidelines on sustainability and the EU investment policies on sustainable and socially responsible business practices. Thus, they argue that in any event the change is inevitable, and, therefore, there is a vital need for future leaders educated in sustainability.

\section{Discussion and Conclusions}

To the best of our knowledge, there is currently no tool available for assessing the necessary inclusion of sustainability in university studies. National and international organizations are working to include sustainability competencies in the teaching curricula in such a way that both teachers and students can attain an optimal degree of knowledge in this matter. In accordance with this rationale, the objective of this study is to support education in sustainability at the university level, taking as a starting point the sustainability competencies formulated by the Executive Committee of the Conference of Rectors of Spanish Universities [42] at a national level and those contained in the UNESCO document: Education for Sustainable Development Goals: learning objectives [21]. For this purpose, the study presents a competency map that aims at assessing sustainability in the specific context of BAM studies, elaborated within the EDINSOST2-SDG project.

We believe that the SCM for BAM presented here will facilitate the design of different methodologies by the teaching staff in order to guide students towards compliance with the 17 SDGs in 2030. Although the SCM-LOs in the map do not need to be covered by all the subjects of BAM degrees, it could serve as a guide when designing a curriculum adapted to the needs of society: making our world a sustainable world. In this sense, the SCM presented in this study is the contribution to the scholars that already worked on the integration of sustainability into Education study programs (e.g., Moreno-Pino et al. [53]) and Engineering (e.g., SanchezCarracedo et al. [54]), and who were calling for its implementation in other fields. Thus, this study responds to this call by proposing the SCM adapted specifically to the studies in BAM.

An additional value of this study is the evaluation of the SCM for BAM by the top representatives of businesses, as future employers of the university graduates and agents with an important role to play in the sustainability of the planet. In particular, using the qualitative research framework, we collected insights from the founders and/or top management of five companies that vary in size and industry. This data allowed us to 
obtain the qualitative evaluation of the MCS by another important stakeholder without a direct link to academia. In this sense, the external evaluation of competency maps was mostly done through the insights from the internal stakeholders of the educational process, such as teachers and trainers [55] or students [54]. This study contributes external insights from another very important stakeholder, which is graduates' potential employers, and sheds new light to the issue of the integration of sustainability in higher education.

First, the holistic dimension of the SCM for BAM received particular praise, and for some interviewees it proved to be revelatory, since their understanding of sustainability was that of minimizing the negative environmental externalities of a company's activities. For others, the map highlighted the handicaps in some areas of sustainability of their company. Thus, we believe that the holistic understanding of sustainability enables differentiation between greenwashing and authentic sustainability. In particular, only those companies that strive for or achieve holistic sustainability can be regarded as truly sustainable, and only those managers who understand this concept as holistic are able to direct their strategy towards authentic sustainability. In this regard, the map can be a helpful tool for understanding the concept of sustainability in multidimensional terms, where each side forms part of and is indispensable from the whole, unlike other similar projects that tend to understand sustainability from the viewpoint of spent resources and environmental externalities [56].

Second, the MCS's division of competencies into three levels and its representation met with a highly positive response from the interviewees, whose concerns were the lack of a universally accepted understanding of sustainability and the difficulties involved in its measurement as well as the plurality of the different tools employed to address it (such as the measurement of social and/or environmental impact). Indeed, concerns about measuring the competencies acquired by students are very well-founded, since it is an area where making measurements in practice involves significant difficulties. In this regard, the interviewees were surprised by the usefulness of the SCM for BAM and its ability to compensate for the absence of measurement tools. Such a representation of the different levels across a range of sustainability dimensions in the form of a handy table would enable both managers and employees to evaluate their own sustainable performance and thereby shape their strategies accordingly. Furthermore, the interviewees expressed their wish to see impact measurements or other related tools included in the curricula of BAM students. Given their vast plurality, students' knowledge about them, together with their ability to evaluate their strength and weaknesses and compare those which could be the most appropriate for a particular company and/or activity, as future employees, would provide inestimable assistance for a company's pathway towards sustainability.

In addition, the real application of the SCM for BAM in a classroom should be carried out strategically throughout various stages, starting from the faculty head office (in order to adapt the program curricula) and teacher training (to adapt the curricula of the subjects). While the added value of the SCM presented here, as perceived by the interviewees, has been demonstrated in terms of its practical application, a gap still remains between the SCM for BAM as a theoretical model and the competencies taught in the classroom and acquired by the students. Closing this gap might entail resistance to change, infamously known as the "university immune system" [57], and thus requires a concerted effort from the various HEIs stakeholders. In this sense, the special value of projects such as EDINSOST2SDG forms part of the complementary plurality of the different activities, one of which is specifically designed to overcome this challenge, that is, educational workshops especially aimed at teachers to enable them to understand how they can introduce sustainability in their subjects and what activities they can undertake to work on the sustainability competencies. We are convinced that there are virtually no subjects within the field of BAM in which sustainability competencies cannot be worked on and there are none which cannot be achieved with the full commitment of an expert teacher. Accordingly, we invite the academic community to take up this initiative and explore how sustainability competencies 
can be addressed as part of BAM studies and to make use of tools such as that proposed herein to attain that goal.

Moreover, because of the alignment of the proposed map with the SDG-LOs put forth and recommended by UNESCO, it can be implemented universally. Thus, although the study was conducted in the very specific context of the Spanish Higher Education system, its results can be transferred to other institutional environments, and generate impact in geographical location far beyond the original research settings. In this regard, multiple studies pointed at the cultural limitations of some frameworks of sustainability competencies in higher education [58], highlighting that they tend to be instilled in a very specific cultural/national setting, or even an institution, calling for more transferable frameworks that could be applied worldwide. This study is an attempt to respond to this call.

Finally, the qualitative data has enabled us to appreciate the importance of education in sustainability for future business leaders. According to the interviewees, it is only by means of the leaders educated in sustainability as a holistic concept, unframed within the silo of a separate topic or subject, but rather as one which transcends their BAM studies, that the systemic change towards sustainability can become a reality. If the strategic vision of leaders is based on and shaped by sustainability, they will be able to communicate it to their employees, who stand on the frontline between the company and the customer. In turn, these employees will also be able to transmit the added value of sustainability to their customers, so that rather than being pulled from the outside by niche customers demanding safer products, by potential employees striving for their basic rights or by governments pursuing policies for sustainable development, businesses will drive the paradigmatic change towards sustainability from within.

Author Contributions: Conceptualization, D.G.-D. and E.J.S.-A.; methodology, M.L.-L., N.M., and D.G.-D.; writing — original draft preparation, all authors; writing — review and editing, all authors. All authors have read and agreed to the published version of the manuscript.

Funding: This work was supported by the Spanish Ministerio de Economía y Competitividad, from study design to submission, under grant number EDU2015-65574-R; by the Spanish Ministerio de Ciencia, Innovación y Universidades, the Spanish Agencia Estatal de Investigación (AEI) and the Fondo Europeo de Desarrollo Regional (FEDER), from study design to submission, under grant number RTI2018-094982-B-I00.

Institutional Review Board Statement: Not applicable.

Informed Consent Statement: Not applicable.

Conflicts of Interest: The authors declare no conflict of interest. The funders had no role in the design of the study; in the collection, analyses, or interpretation of data; in the writing of the manuscript, or in the decision to publish the results. 


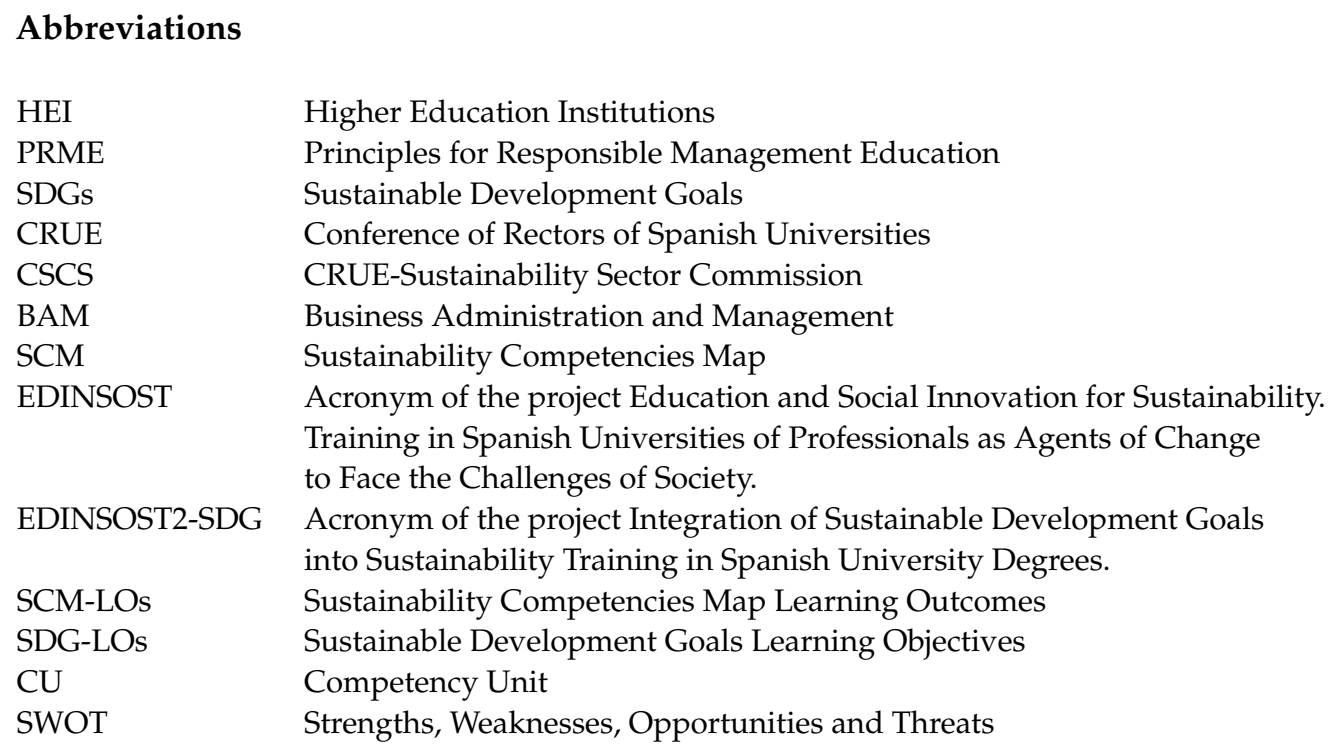

Appendix A

List of SCM-LOs

- C1.HO.1.1. Knows the concepts of Sustainability and Sustainable Development and its different dimensions (environmental, social, economic).

- C1.HO.1.2. Knows the main causes, consequences and stakeholders involved in social, economic and/or environmental problems, both locally and globally.

- C1.HO.1.3. Knows the solutions proposed for these problems (for example, Sustainable Development Goals of the 2030 Agenda, IPCC reports).

- C1.HO.2.1. Critically reflects on the different dimensions of sustainability in the analysis of a situation related to their professional field.

- C1.HO.3.1. Is able to relate a problem of sustainability of a product or service in their professional field with the methods and strategies used to tackle it.

- C2.EN.1.1. Knows metrics (or tools) to measure the environmental impact of products and services related to their professional field (for example, environmental footprint, polluting emissions, resource/energy consumption, environmental impact matrix, impact on biodiversity, waste generation, Directive 2014/95/EU for non-financial reporting).

- C2.EN.1.2. Knows strategies and/or technologies for reducing, reusing and recycling natural resources and waste related to the products and services in their professional field.

- C2.EN.2.1. Knows how to use the appropriate metrics (or tools) to measure the environmental impact of the use of products and services related to their professional field (for example, environmental footprint, polluting emissions, resource/energy consumption, environmental impact matrix, impact on biodiversity, waste generation, Directive 2014/95/EU for non-financial reporting).

- C2.EN.2.2. Is aware of the environmental impact that products and services related to their professional field have throughout their life cycle (extraction, production, use and end of life).

- C2.EN.3.1. Takes into account environmental criteria in projects related to their professional field.

- C2.EN.3.2. Includes in their projects indicators to estimate/measure the environmental impact (for example, environmental footprint, polluting emissions, resource/energy consumption, environmental impact matrix, impact on biodiversity, generation of waste, Directive 2014/95/EU for non-financial reporting).

- C2.EN.3.3. Is able to contribute to the improvement of the environment and the prevention of harmful impacts through their professional activity. 
- C2.SO.1.1. Knows the metrics (or tools) that measure and describe the social impact of products and services related to their professional field (for example, Social Life Cycle Analysis, ISO 26000, Directive 2014/95/EU for non-financial reporting).

- C2.SO.1.2. Knows basic concepts about social justice related to their professional field (for example, equality, diversity, common good, transparency, human rights, gender perspective, needs of the most vulnerable groups, discrimination, dignity, fight against corruption).

- $\quad$ C2.SO.2.1. Knows how to use the appropriate indicators to measure the social impact of the products and services related to their professional field (for example, Social Life Cycle Analysis, ISO 26000, Directive 2014/95/EU for non-financial reporting).

- C2.SO.2.2. Understands the direct and indirect consequences that products and services related to their professional field have on social justice (for example, equality, diversity, common good, transparency, human rights, gender perspective, needs of the most vulnerable groups, discrimination, dignity, fight against corruption).

- C2.SO.3.1. Includes indicators in their projects to measure social impact (for example, Social Life Cycle Analysis, ISO 26000, Directive 2014/95/EU for non-financial reporting).

- C2.SO.3.2. Takes into account social justice criteria in their projects (for example, equality, diversity, common good, transparency, human rights, gender perspective, needs of the most vulnerable groups, discrimination, dignity, fight against corruption).

- $\quad$ C2.EC.1.1. Knows the basic concepts of resource management applicable in project management in their professional field (for example, fixed and variable costs, amortizations, budgets, Gantt charts).

- C2.EC.1.2. Knows the methods (or tools) to estimate the economic viability of a project in their professional field (for example, externalities analysis, CANVAS analysis, SWOT analysis, business plan, strategic planning, cost-benefit analysis).

- C2.EC.2.1. Analyzes real cases of resource management.

- C2.EC.2.2. Understands the economic viability plan of a project in their professional field (for example, externalities analysis, CANVAS analysis, SWOT analysis, business plan, strategic planning, cost-benefit analysis).

- C2.EC.2.3. Identifies the economic consequences that a project or service their professional field might have on society.

- C2.EC.3.1. Is able to plan a project in their professional field (both short and long-term) and to elaborate a complete budget based on the material and human resources required.

- C2.EC.3.2. Is able to carry out an economic viability plan for a project in their professional field (for example, externalities analysis, CANVAS analysis, SWOT analysis, business plan, strategic planning, cost-benefit analysis).

- C2.EC.3.3. Is able to economically monitor the development of a project in their professional field and detect deviations from the initial planning.

- C2.EC.3.4. Is able to monitor the financial management of a project in their professional field throughout its useful life.

- C2.HO.1.1. Knows direct and indirect consequences of the use of products and services related to their professional field for society, the economy and the environment.

- C2.HO.1.2. Knows the strategic role of their profession in sustainability.

- C2.HO.1.3. Knows different economic approaches that promote sustainable development (for example, circular economy, the economy of the common good, social economy, ecological economy).

- C2.HO.1.4. Knows the roles, rights and duties that different stakeholders (professionals, companies, legislation, clients, consumers, etc.) have in the production and consumption of products and services related to their professional field.

- C2.HO.2.1. Is able to critically assess the impact (positive and negative) that products and services related to their professional field may have on society, the economy and the environment. 
- $\quad$ C2.HO.2.2. Knows how to analyze different alternatives of a product or service in their professional field to decide which is the most sustainable and evaluate to what extent it solves the problem posed.

- C2.HO.2.3. Knows how to critically assess whether the economic viability of a project in their professional field is compatible with the environmental and social aspects of sustainability.

- C2.HO.2.4 Knows how to apply tools for sustainability in production, consumption and recycling.

- C2.HO.3.1. Is capable of proposing sustainable projects in their professional field, taking into account environmental, economic and social aspects.

- C2.HO.3.2. Is capable of monitoring a project to make it sustainable.

- C2.HO.3.3. Is able to contribute new ideas and solutions to a project in their professional field to make it more sustainable in order to improve the sustainability of products, processes or services.

- $\quad$ C2.HO.3.4. Is able to select which indicators will be used to measure the sustainability of their projects in the different dimensions: environmental, social and economic.

- $\quad$ C3.HO.1.1. Knows examples of projects in their professional field that involve different actions (information, consultation, participation, integration) and/or consider the needs and expectations of related stakeholders.

- $\quad$ C3.HO.1.2. Knows techniques and/or tools to achieve different degrees of interaction with the stakeholders involved in a project or in a sustainability challenge.

- C3.HO.1.3. Knows how the activity in their professional field influences other social, economic and environmental stakeholders, and with the interest groups related to the activity.

- C3.HO.2.1. Given a project in their professional field and collaborating with the stakeholders involved, know how to identify the needs and expectations of the different interest groups and how to assess their implications for the sustainability of the project.

- C3.HO.3.1. Is capable of acting as an agent of change, participating from their professional field in reflection and decision-making processes that guide society towards sustainable transitions.

- C3.HO.3.2. Is able to use techniques and/or tools to achieve different degrees of interaction, in an interdisciplinary context, with the stakeholders and groups of interest participating in a project or sustainability challenge.

- C4.HO.1.1. Knows the main ethical issues related to sustainability in their professional field.

- $\quad$ C4.HO.1.2. Knows the ethical principles that underpin the values of sustainability (for example, equality, justice, precautionary principle, prevention of damage, responsibility before present and future generations, protection and restoration of a healthy environment, social, economic and environmental human rights).

- C4.HO.1.3. Knows the concepts of social commitment and corporate social responsibility, their possibilities and limitations.

- C4.HO.1.4. Knows the deontological principles of their profession as well as the laws and regulations related to sustainability in their professional field.

- C4.HO.2.1. Is able to identify and critically assess the implications of ethical and deontological principles related to the values of sustainability in their professional field.

- C4.HO.2.2. Is able to critically assess the responsible actions of companies, as well as the implications that ethical and deontological principles have for the projects, products and services in their professional field.

- C4.HO.3.1. Is able to practice their profession, taking into account the ethical principles related to the values of sustainability (for example equality, justice, precautionary principle, prevention of damage, responsibility for present and future generations, protection and restoration of a healthy environment, social, economic and environmental human rights). 
- C4.HO.3.2. Is capable of actively participating in responsible action in the entities in which they develop their profession.

\section{References}

1. Cortese, A.D. The critical role of higher education in creating a sustainable future. Plan. High. Educ. 2003, 31, 15-22.

2. Leal Filho, W. About the role of universities and their contribution to sustainable development. High. Educ. Policy 2011, 24, 427-438. [CrossRef]

3. UNESCO. Draft International Implementation Scheme for the United Nations Decade of Education for Sustainable Development (2005-2014); United Nations Educational, Scientific and Cultural Organization: Paris, France, 2003.

4. UNESCO. Aichi-Nagoya Declaration on Education for Sustainable Development; United Nations Educational, Scientific and Cultural Organization: Aichi-Nagoya, Japan, 2014.

5. UNESCO. Implementation of Education for Sustainable Development in the Framework of the 2030 Agenda for Sustainable Development; United Nations Educational, Scientific and Cultural Organization: Paris, France, 2019.

6. Lozano, R. Sustainable Development in Higher Education Incorporation, Assessment, and Reporting of Sustainable Development in Higher Education Institutions. Master's Thesis, Lund University, Lund, Sweden, 2003.

7. SDSN. Getting Started with the SDGs in Universities: A Guide for Universities, Higher Education Institutions, and the Academic Sector; Sustainable Development Solutions Network (SDSN): Melbourne, Australia, 2017.

8. SDSN. Accelerating Education for the SDGs in Universities: A Guide for Universities, Colleges, and Tertiary and Higher Education Institutions; Sustainable Development Solutions Network (SDSN): New York, NY, USA, 2020.

9. GUNi. Implementing the 2030 Agenda at Higher Education Institutions: Challenges and Responses; Global University Network for Innovation (GUNi): Barcelona, Spain, 2019.

10. Expósito, L.M.C.; Granados-Sánchez, J. Implementation of SDGs in university teaching: A course for professional development of teachers in education for sustainability for a transformative action. Sustainability 2020, 12, 8267. [CrossRef]

11. Azcárate, P.; Navarrete, A.; García, E. Aproximación al nivel de inclusión de la sostenibilidad en los curricula universitarios. Profesorado. Rev. Currículum Form. Profr. 2012, 16, 105-119.

12. Leal Filho, W.; Wu, Y.C.J.; Brandli, L.L.; Avila, L.V.; Azeiteiro, U.M.; Caeiro, S.; Madruga, L.R.D.R.G. Identifying and overcoming obstacles to the implementation of sustainable development at universities. J. Integr. Environ. Sci. 2017, 14, 93-108. [CrossRef]

13. Ahmadein, G. Obstacles and opportunities for achieving the SDGs at higher education institutions: A regional Arab perspective. In Implementing the 2030 Agenda at Higher Education Institutions: Challenges and Responses; Global University Network for Innovation (GUNi): Barcelona, Spain, 2019; pp. 15-22.

14. Larrán, M.; Andrades, F.J. Implementing sustainability and social responsibility initiatives in the higher education system: Evidence from Spain. In Integrative Approaches to Sustainable Development at University Level; Springer: Cham, Switzerland, 2015; pp. 113-128.

15. Lidgren, A. A Sustainable Course for Higher Education. Master's Thesis, Lund University, Lund, Sweden, 2004.

16. Leal Filho, W.; Levesque, V.R.; Salvia, A.L.; Paço, A.; Fritzen, B.; Frankenberger, F.; Damke, L.I.; Brandli, L.L.; Ávila, L.V.; Mifsud, M.; et al. University teaching staff and sustainable development: An assessment of competences. Sustain. Sci. 2021, 16, 101-116. [CrossRef]

17. Eizaguirre, A.; García-Feijoo, M.; Laka, J.P. Defining sustainability core competencies in business and management studies based on multinational stakeholders' perceptions. Sustainability 2019, 11, 2303. [CrossRef]

18. Barth, M.; Godemann, J.; Rieckmann, M.; Stoltenberg, U. Developing key competencies for sustainable development in higher education. Int. J. Sustain. High. Educ. 2007, 8, 416-430. [CrossRef]

19. Sipos, Y.; Battisti, B.; Grimm, K. Achieving transformative sustainability learning: Engaging head, hands and heart. Int. J. Sustain. High. Educ. 2008, 9, 68-86. [CrossRef]

20. Wiek, A.; Withycombe, L.; Redman, C.L. Key competencies in sustainability: A reference framework for academic program development. Sustain. Sci. 2011, 6, 203-218. [CrossRef]

21. UNESCO. Education for Sustainable Development Goals: Learning Objectives; United Nations Educational, Scientific and Cultural Organization: Paris, France, 2017.

22. Brundiers, K.; Wiek, A. Beyond interpersonal competency: Teaching and learning professional skills in sustainability. Educ. Sci. 2017, 7, 39. [CrossRef]

23. Wamsler, C.; Brossmann, J.; Hendersson, H.; Kristjansdottir, R.; McDonald, C.; Scarampi, P. Mindfulness in sustainability science, practice, and teaching. Sustain. Sci. 2018, 13, 143-162. [CrossRef] [PubMed]

24. Papenfuss, J.; Merritt, E.; Manuel-Navarrete, D.; Cloutier, S.; Eckard, B. Interacting pedagogies: A review and framework for sustainability education. J. Sustain. Educ. 2019, 20, 19.

25. Redman, A.; Wiek, A.; Barth, M. Current practice of assessing students' sustainability competencies: A review of tools. Sustain. Sci. 2021, 16, 117-135. [CrossRef]

26. Tamsin, F.; Wiek, A. A process-oriented framework of competencies for sustainability entrepreneurship. Sustainability 2019, 11, 7250 .

27. De Oliveira, A.C.; Sokulski, C.C.; da Silva Batista, A.A.; de Francisco, A.C. Competencies for sustainability: A proposed method for the analysis of their interrelationships. Sustain. Prod. Consum. 2018, 14, 82-94. [CrossRef] 
28. Knight, B.; Paterson, F. Behavioural competencies of sustainability leaders: An empirical investigation. J. Organ. Chang. Manag. 2018, 1, 557-580. [CrossRef]

29. Olalla, C.B.; Merino, A. Competences for sustainability in undergraduate business studies: A content analysis of value-based course syllabi in Spanish universities. Int. J. Manag. Educ. 2019, 17, 239-253. [CrossRef]

30. Delors, J. Learning: The Treasure within; Report to UNESCO of the International Commission on Education for the Twenty-First Century; United Nations Educational, Scientific and Cultural Organization: Paris, France, 1996.

31. UNESCO. Education for All by 2015: Will We Make It? EFA Global Monitoring Report; United Nations Educational, Scientific and Cultural Organization: Paris, France, 2007.

32. Willard, M.; Wiedmeyer, C.; Warren Flint, R.; Weedon, J.S.; Woodward, R.; Feldman, I.; Edwards, M. The sustainability professional: 2010 competency survey report. Environ. Qual. Manag. 2010, 20, 49-83. [CrossRef]

33. Dentoni, D.; Blok, V.; Lans, T.; Wesselink, R. Developing human capital for agri-food firms' multi-stakeholder interactions. Int. Food Agribus. Manag. Rev. 2012, 15, 61-68.

34. Lans, T.; Blok, V.; Wesselink, R. Learning apart and together: Towards an integrated competence framework for sustainable entrepreneurship in higher education. J. Clean. Prod. 2014, 62, 37-47. [CrossRef]

35. Adomßent, M.; Fischer, D.; Godemann, J.; Herzig, C.; Otte, I.; Rieckmann, M.; Timm, J. Emerging areas in research on higher education for sustainable development-management education, sustainable consumption and perspectives from Central and Eastern Europe. J. Clean. Prod. 2014, 62, 1-7. [CrossRef]

36. Herzig, C.; Moon, J. Discourses on corporate social ir/responsibility in the financial sector. J. Bus. Res. 2013, 66, 1870-1880. [CrossRef]

37. Hesselbarth, C.; Schaltegger, S. Educating change agents for sustainability-learnings from the first sustainability management master of business administration. J. Clean. Prod. 2014, 62, 24-36. [CrossRef]

38. Cole, R.; Snider, B. Managing in turbulent times: The impact of sustainability in management education on current and future business leaders. J. Clean. Prod. 2019, 210, 1622-1634. [CrossRef]

39. Westerman, J.W.; Nafees, L.; Westerman, J. Cultivating support for the sustainable development goals, green strategy and human resource management practices in future business leaders: The role of individual differences and academic training. Sustainability 2021, 13, 1050-2071. [CrossRef]

40. PRME. Principles for Responsible Management Education. Available online: https://www.unprme.org/ (accessed on 25 May 2021).

41. Godemann, J. Sustainable communication as an inter-and transdisciplinary discipline. In Sustainability Communication; Godemann, J., Michelsen, G., Eds.; Springer: Dordrecht, The Netherlands, 2011; pp. 39-51.

42. CRUE. Directrices para la Introducción de la Sostenibilidad en el Curriculum; Conferencia de Rectores de las Universidades Españolas (CRUE): Valencia, Spain, 2012.

43. Sánchez-Carracedo, F.; Segalàs, J.; Vidal, E.; Martin, C.; Climent, J.; López, D.A.; Cabré, J. Improving engineering educators' sustainability competencies by using competency maps: The EDINSOST project. Int. J. Eng. Educ. 2018, 34, $1527-1537$.

44. Sánchez-Carracedo, F.; Ruiz-Morales, J.; Valderrama-Hernández, R.; Muñoz-Rodríguez, J.M.; Gomera, A. Analysis of the presence of sustainability in higher education degrees of the Spanish university system. Stud. High. Educ. 2021, 46, 300-317. [CrossRef]

45. Hartel, R.W.; Foegeding, E.A. Learning: Objectives, competencies, or outcomes? J. Food Sci. Educ. 2004, 3, 69-70. [CrossRef]

46. Albareda-Tiana, S.; Ruíz-Morales, J.; Azcárate, P.; Valderrama-Hernández, R.; Múñoz, J.M. The EDINSOST project: Implementing the sustainable development goals at university level. In Universities as Living Labs for Sustainable Development; Springer: Cham, Switzerland, 2020; pp. 193-210.

47. Sánchez-Carracedo, F.; Moreno-Pino, F.M.; Sureda, B.; Antúnez, M.; Gutiérrez, I. A methodology to analyze the presence of sustainability in engineering curricula. Case of study: Ten Spanish engineering degree curricula. Sustainability 2019, 11, 4553. [CrossRef]

48. Gil-Doménech, D.; Berbegal-Mirabent, J.; Diestra, G. Valoraciones del proyecto. In B-SMART: Connecting University E Business; Berbegal-Mirabent, J., Gil-Doménech, D., Eds.; OmniaScience: Barcelona, Spain, 2020; pp. 141-162.

49. Polkinghorne, D.E. Narrative configuration in qualitative analysis. Qual. Stud. Educ. 1995, 8, 5-23. [CrossRef]

50. Olsson, S.; Malmqvist, T.; Glaumann, M. Managing sustainability aspects in renovation processes: Interview study and outline of a process model. Sustainability 2015, 7, 6336-6352. [CrossRef]

51. Gioia, D.A.; Corley, K.G.; Hamilton, A.L. Seeking qualitative rigor in inductive research: Notes on the Gioia methodology. Organ. Res. Methods 2013, 16, 15-31. [CrossRef]

52. Miller, G.E. The assessment of clinical skills/competence/performance. Acad. Med. 1990, 65, 63-67. [CrossRef]

53. Moreno-Pino, F.M.; Jiménez-Fontana, R.; Cardeñoso Domingo, J.M.; Azcárate Goded, P. Study of the presence of sustainability competencies in teacher training in mathematics education. Sustainability 2021, 13, 5629. [CrossRef]

54. Sánchez-Carracedo, F.; Sureda, B.; Moreno-Pino, F.M.; Romero-Portillo, D. Education for sustainable development in Spanish engineering degrees. Case study. J. Clean. Prod. 2021, 294, 126322. [CrossRef]

55. Busquets, P.; Segalas, J.; Gomera, A.; Antúnez, M.; Ruiz-Morales, J.; Albareda-Tiana, S.; Miñano, R. Sustainability education in the Spanish higher education system: Faculty practice, concerns and needs. Sustainability 2021, 13, 8389. [CrossRef]

56. Schopp, K.; Bornemann, M.; Potthast, T. The whole-institution approach at the University of Tübingen: Sustainable development set in practice. Sustainability 2020, 12, 861. [CrossRef] 
57. Gilley, A.; Godek, M.; Gilley, J.W. The university immune system: Overcoming resistance to change. Contemp. Issues Educ. Res. 2009, 2, 1-6. [CrossRef]

58. Brundiers, K.; Barth, M.; Cebrián, G.; Cohen, M.; Diaz, L.; Doucette-Remington, S.; Dripps, W.; Habron, G.; Harré, N.; Jarchow, M.; et al. Key competencies in sustainability in higher education-Toward an agreed-upon reference framework. Sustain. Sci. 2021, 16, 13-29. [CrossRef] 